\section{Basic concepts and research activities at Italian forest sites of the Long Term Ecological Research network}

\author{
Cocciufa $C^{(1)}$, Cerretti $P^{(2)}$, Matteucci $G^{(3-4)}$, Carpaneto GM ${ }^{(5)}$
}

Italy entered the International Long Term Ecological Research Network (ILTER) in 2006, contributing a group of research sites in marine, freshwater and terrestrial ecosystems to the global network. Five forest sites are included in the Italian Network. They are representative of the main forest ecosystems in Italy and integrate 15 research stations managed by different institutes. Starting from LTER rationale and basic concepts, the first part of the paper reviews the status of LTER Italy forest sites, the strengths resulting from multidisciplinary expertise and site management, current activities and available datasets. Long term data series on key environmental parameters show the high scientific value of these sites, where monitoring and/or research is still ongoing. But two main LTER issues are currently arising in the international context: (1) overall consistency of datasets; (2) harmonization of sampling methods. For this reason, the second part of the paper investigates the suitability of Italian forest sites to address recommended long term research topics and ecological issues of global concern and to investigate the shift from in-site monitoring to crosssite cooperation and inter-site research.

Keywords: Long term ecological research, Forest ecosystems, Research site, Datasets, Methodology, Biodiversity

\section{Introduction}

The International Long Term Ecological Research Network (ILTER)

The long term ecological research (LTER) was founded in 1993 in order to work at local, regional and national level to share data, cooperate on global projects, integrate findings and deliver peer-reviewed research to decision-makers and the public (Kaufmann \& Anderson 2006). In the United States, studies of ecosystems based on sites (forest, watershed and rangeland) started in the early 1900s (Peters 2010). Currently, the international long term ecological research (ILTER) network (http://www.ilternet.edu/) involves 40 contributing countries (Tab. 1), reflecting the increased importance of long term research in addressing complex environmental issues at global scale. Italy entered the ILTER Network in 2006, following the initiative of a core group of experts from National Forest Service (Corpo Forestale dello Stato), National Research Council (Consiglio Nazionale delle Ricerche), Anthon Dohrn Zoological Station and Italian Society of Ecology. At the moment, LTER Italy (http://www.lteritalia.it/) consists of an integrated group of 20 sites in terrestrial, freshwater and marine ecosystems, where long term ecological monitoring is performed and historical dataset series are maintained and updated. Among terrestrial sites, five sites represent forest ecosystems. Eighteen research institutes and university departments are responsible for coordination of scientific activities at LTER Italy sites. The national coordination of LTER is currently run by the National Research Council.

\section{The basic concepts of Long Term Eco- logical Research}

The most peculiar trait of long term studies is the historical data series they can rely on. A three to five years project is usually considered a long term study, just because it extends over the usual duration of classical projects (1 to 3 years); actually, it would be correct to label a research project as a long term study in relation to the time span of the target ecosystem cycle, that is only in case the study goes on for as long as the ecosystem process under investigation (Strayer et al. 1986). Long term studies have been building valuable historical ecological datasets across the world and addressing questions that involve phenomena that could be partially or incorrectly evaluated when observed over short (1-2 years) time scales (Risser 1991, Magurran et al. 2010). As a consequence, candidate subjects for long term studies are: (1) slow phenomena; (2) subtle patterns, obscured in large matrices of data; (3) rare events; (4) complex processes, depending on multiple variables (Likens 1989, Risser 1991, Magurran et al. 2010). $\square$ (1) CFS, Monitoraggio Ambientale e CONECOFOR, v. G. Carducci 5, I-00186 Rome (Italy); (2) CFS-CNBF, Centro Nazionale per lo Studio e la Conservazione della Biodiversità Forestale Bosco della Fontana, v. C. Ederle 16/a, I-37100 Verona (Italy); (3) CNR, Istituto per i Sistemi Agricoli e Forestali del Mediterraneo (ISAFOM), Rende (CS -Italy); (4) Istituto di Biologia AgroAmbientale e Forestale (IBAF), v. Salaria km 29.300, I-00015 Monterotondo Scalo (Roma Italy); (5) Dipartimento di Biologia Ambientale, Università degli Studi Roma Tre, v.le G Marconi 446, I-00146 Roma (Italy)

\section{@) Cristiana Cocciufa \\ (cristianacocciufa@gmail.com)}

Received: Sep 27, 2010 - Accepted: Apr 08, 2011

Citation: Cocciufa C, Cerretti P, Matteucci G, Carpaneto GM, 2011. Basic concepts and research activities at Italian forest sites of the Long Term Ecological Research network. iForest 4: 233-241 [online 2011-11-03] URL: http://www.sisef.it/iforest/show.php? id $=576$

Long term studies are usually related to the health or functioning of ecosystems and may help in understanding ecosystem responses to global environmental changes. Lindenmayer \& Likens (2009) have proposed the paradigm of adaptive monitoring for long term ecological research. The concept encompasses the maintenance of long term monitoring on a core set of variables, but with a background research question. As data collection goes on, the focused target question can change or evolve into a new question and monitoring adapts along an iterative and flexible process, where sampling design and overall analytical approach can be adjusted, keeping the integrity of long term series. Five core areas have been suggested for long term investigation of ecosystem processes (Strayer et al. 1986, Likens 1989, Risser 1991): (1) spatial and temporal distribution of populations; (2) pattern and frequency of disturbance; (3) pattern and control of primary production; (4) pattern and control of organic matter accumulation; (5) pattern of inorganic input and movements through soils. Moreover, ecological large scale phenomena of global concern like climate change, pollution, impact of management and land use change, biodiversity loss and distribution of invasive species comfortably match the LTER concept (Strayer et al. 1986, Likens 1989, Risser 1991). On the other side, studies on individual species, species lists or indices derived from species lists are generally not suitable to long term ecolo- 
gical research, as this kind of studies requires equivalency among sites, which is hardly respected across huge environmental gradients like those covered by LTER sites (Seastedt \& Briggs 1991).

\section{Characteristics of LTER sites}

Long term ecological research relies on a scientific approach that is strongly sitebased. Though indoor experiments may be performed and modeling can be used to explore and use datasets (Likens 1989), basically long term ecological research works on a network of sites and/or research facilities across the world, where field observations and sampling are performed. According to an ex-post rule adopted within the European LTER governance structure (http://www.ltereurope.net/), a LTER "site" is a research and /or monitoring facility, that can be made up by one or more "research stations" (field sta- tions - Tab. 2). But LTER governance structure and research mandate are built on a bottom-up rather than a top-down approach (Parr et al. 2002), thus creating a collection of sites rather than a network with a specific systematic or stratified design. Generally, sites represent habitat types in terrestrial, freshwater and marine ecosystems and are selected given the accomplishment of the following criteria: (1) the existence of long series of ecological data; (2) the development of research activities on ecological issues of global concern (biodiversity loss, climate change, land use change etc.); and finally (3) an open policy for cross-site scientific cooperation (Kaufmann \& Anderson 2006). So, for the existing networks, a post-hoc adaptation of sites and measurements is strongly advised, thought it may open the way to methodological issues (Beard et al. 1999, Sutherland 2006).

\section{Forest sites within LTER Italy}

LTER Italy includes five sites representing forest ecosystems (Tab. 3): (1) Forests of the Alps, made up of 5 stations, where the main biotic communities are primary and secondary stands dominated by spruce (Picea abies L.); (2) Forests of the Apennines, whose three stations are Fagus sylvatica L. high forests and coppice stands, the latter mixed with secondary meadows; (3) Mediterranean forests, represented by mixed old coppice of Quercus ilex L. and Quercus cerris L. dominated forests, over four stations; (4) Castelporziano Estate, including relevant patches of mixed deciduous oak forest (Quercus cerris L., Quercus frainetto TEN., Quercus robur L.), Mediterranean evergreen oak forest (Quercus ilex L., Quercus suber L.) and Mediterranean pine forest (Pinus pinea L.), once covering the whole estuary of the river Tevere and the surrounding landscape, to-

Tab. 1 - ILTER member Countries (http://www.ilternet.edu/).

\begin{tabular}{|c|c|c|}
\hline Continent & $\begin{array}{l}\text { ILTER member } \\
\text { Country }\end{array}$ & Name of the National LTER Network \\
\hline \multirow[t]{7}{*}{ America } & Canada & EMAN - Ecological Monitoring and Assessment Network \\
\hline & U.S.A. & US LTER - United States Long Term Ecological Research Network \\
\hline & Mexico & Mex LTER - Red Mexicana de Investigación Ecológica a Largo Plazo \\
\hline & Costa Rica & CRLTER - Costa Rica Long Term Ecological Research Network \\
\hline & Venezuela & ECORED - Red Venezolana de Estaciones de Investigación Ecológica a Largo Plazo \\
\hline & Brazil & PELD - Pesquisas Ecológicas de Longa Duração \\
\hline & Uruguay & IELDU - Investigaciones Ecológicas de Larga Duración \\
\hline \multirow[t]{19}{*}{ Europe } & Finland & FinLTSER - Finnish Long Term Socio-Ecological Research Network \\
\hline & Latvia & LTERLatvia - Latvia Long Term Ecological Research Network \\
\hline & Lithuania & Lithuanian LTER - Lithuanian Long Term Ecological Research Network \\
\hline & U.K. & ECN - Environmental Change Network \\
\hline & Germany & LTER-D - German Long Term Ecological Research Network \\
\hline & Poland & LTER Poland - Polish Long Term Ecological Research Network \\
\hline & Czech Republic & CZLTER - Czech Long Term Ecological Research Network \\
\hline & Slovakia & LTER Slovakia - Slovak Long Term Ecological Research Network \\
\hline & Austria & LTER Austria - Austrian Long Term Ecological Research Network \\
\hline & Slovenia & LTER Slovenia - Slovenia Long Term Ecological Research Network \\
\hline & Romania & LTER Romania - Romanian Long Term Ecological Research Network \\
\hline & Hungaria & LTER Hungaria - Hungarian Long Term Ecological Research Network \\
\hline & Serbia & LTER Serbia - Serbia Long Term Ecological Research Network \\
\hline & Bulgaria & LTER Bulgaria - Bulgarian Long Term Ecological Research Network \\
\hline & Switzerland & LWF - Switzerland Long Term Forest Ecosystem Research \\
\hline & Italy & LTER Italy - Italian Long Term Ecological Research Network \\
\hline & France & LTER France - French Long Term Ecological Research Network \\
\hline & Spain & LTER Spain - Spanish Long Term Ecological Research Network \\
\hline & Portugal & LTER Portugal - Portugal Long Term Ecological Research Network \\
\hline Middle East & Israel & LTER Israel - Israeli Long Term Ecological Research Network \\
\hline \multirow{5}{*}{ Africa } & Zambia & LTER Zambia - Zambia Long Term Ecological Research Network \\
\hline & Malawi & LTER Malawi - Malawi Long Term Ecological Research Network \\
\hline & Mozambique & LTER Mozambique - Mozambique Long Term Ecological Research Network \\
\hline & Namibia & Gbb EON - Gobabeb Training and Research Centre - Environmental Observation Network \\
\hline & South Africa & SAEON - South African Environmental Observation Network \\
\hline \multirow[t]{7}{*}{ Asia } & Mongolia & Hövsgöl Ecology - Mongolian Long Term Ecological Research Network \\
\hline & China & CERN - Chinese Ecosystem Research Network \\
\hline & Korea & KLTER - Korea Long Term Ecological Research Network \\
\hline & Japan & JaLTER - Japanese Long Term Ecological Research Network \\
\hline & Taiwan & TERN - Taiwan Ecological Research Network \\
\hline & Philipines & LTER Philippines - Philippines Long Term Ecological Research Network \\
\hline & Thailand & LTER Thailand - Thailand Long Term Ecological Research Network \\
\hline Pacific South East & Australia & LTER Australia - Australian Long Term Ecological Research Network \\
\hline
\end{tabular}


Tab. 2 - LTER Europe site main characteristics (Mirtl et al. 2008 - simplified).

\begin{tabular}{ll}
\hline \multicolumn{1}{c}{ Criteria } & \multicolumn{1}{c}{ LTER site feature } \\
\hline Synonym & Traditional LTER site \\
Design & Simple (square, circular, irregular shape area) \\
Consists of & field stations within the site (plots, grid points, equipment) \\
Size & $1-10 \mathrm{~km}^{2}$ \\
Frequency per country & $5-20$ \\
Frequency in Europe & $100-300$ \\
Number of institutions per site & 1 or few \\
Plot scale & Yes \\
Habitat or local scale & Yes \\
Landscape scale & No
\end{tabular}

gether with other different, typically Mediterranean, ecosystems, like the Mediterranean maquis and coastal dunes; (5) Lowland forest "Bosco della Fontana", composed by

three main communities: a mesophilous Quercus robur L. stand, a mesoxerophilous forest with Quercus cerris L. and a mesohygrophilous one with Fraxinus oxycarpa
Bieb. (Campanaro et al. 2007). Ten of the 15 research stations included in forest sites belong to the CONECOFOR Network that started in Italy in 1995, as national branch of the ICP Forests Programme (http://www.icpforests.org), in the framework of Regulation (EC) no. 1091/94 and under the UN-ECE Convention on Long Range Transboundary Air Pollution. In each of these stations, a permanent monitoring plot (pmp) is installed in a fenced $50 \times 50 \mathrm{~m}$ square area. The Programme has the main objective of monitoring the effects of air pollution on the health of forests and has been collecting about 15 years of data on a robust set of environmental parameters at plot level (Tab. 4). Furthermore, five research stations are included in national or regional natural protected areas (Valbona Forest Reserve, Oriental Alps Pre-

Tab. 3 - European forest types and corresponding EUNIS habitats represented by LTER Italy research stations (European Environmental Agency 2007). (*): research stations belonging to the ICP Forests Programme.

\begin{tabular}{|c|c|c|c|c|c|}
\hline \multirow[t]{2}{*}{ Sites } & \multirow{2}{*}{$\begin{array}{l}\text { LTER Italy forest sites } \\
\text { and research stations }\end{array}$} & \multicolumn{2}{|r|}{ European forest types } & \multicolumn{2}{|r|}{ EUNIS Habitat Classification } \\
\hline & & Code & Forest type & Code & Habitat \\
\hline \multirow[t]{5}{*}{$\begin{array}{l}\text { LTER Italy site no. } \\
02 \text { : Forests of the } \\
\text { Alps }\end{array}$} & $\begin{array}{l}\text { *Val Masino } \\
\text { (Val Masino - SO) }\end{array}$ & 6.3 .2 & $\begin{array}{l}\text { Subalpine and mountainous spruce } \\
\text { and mountainous mixed spruce-silver } \\
\text { fir forest }\end{array}$ & G3.1 & Fir and spruce woodland \\
\hline & $\begin{array}{l}\text { *Renon } \\
\text { (Renon - BZ) }\end{array}$ & 6.3 .2 & $\begin{array}{l}\text { Subalpine and mountainous spruce } \\
\text { and mountainous mixed spruce-silver } \\
\text { fir forest }\end{array}$ & G3.1 & Fir and spruce woodland \\
\hline & $\begin{array}{l}\text { *Passo Lavazè } \\
\text { (Daiano - TN) }\end{array}$ & 6.3 .2 & $\begin{array}{l}\text { Subalpine and mountainous spruce } \\
\text { and mountainous mixed spruce-silver } \\
\text { fir forest }\end{array}$ & G3.1 & Fir and spruce woodland \\
\hline & $\begin{array}{l}\text { *Tarvisio } \\
\text { (Tarvisio - UD) }\end{array}$ & 6.3 .2 & $\begin{array}{l}\text { Subalpine and mountainous spruce } \\
\text { and mountainous mixed spruce-silver } \\
\text { fir forest }\end{array}$ & G3.1 & Fir and spruce woodland \\
\hline & $\begin{array}{l}\text { Valbona Reserve } \\
\text { (Predazzo - TN) }\end{array}$ & 6.3 .2 & $\begin{array}{l}\text { Subalpine and mountainous spruce } \\
\text { and mountainous mixed spruce-silver } \\
\text { fir forest }\end{array}$ & G3.1 & Fir and spruce woodland \\
\hline \multirow[t]{3}{*}{$\begin{array}{l}\text { LTER Italy site no. } \\
\text { 03: Apennines } \\
\text { forests }\end{array}$} & $\begin{array}{l}\text { *Selva Piana } \\
(\text { Collelongo - AQ) }\end{array}$ & 6.7 .3 & $\begin{array}{l}\text { Apennine - Corsican mountainous } \\
\text { beech forest } \\
\text { Southern Italian Beech forest }\end{array}$ & G1.68 & Beech woodland \\
\hline & $\begin{array}{l}\text { *Piano Limina } \\
\text { (Giffone - RC) }\end{array}$ & 6.7 .3 & $\begin{array}{l}\text { Apennine - Corsican mountainous } \\
\text { beech forest } \\
\text { Southern Italian Beech forest }\end{array}$ & G1.68 & Beech woodland \\
\hline & $\begin{array}{l}\text { Torricchio Reserve } \\
\text { (Macerata) }\end{array}$ & $\begin{array}{l}6.7 .3 \\
6.8 .8\end{array}$ & $\begin{array}{l}\text { Apennine - Corsican mountainous } \\
\text { beech forest, Other thermophilous } \\
\text { deciduous forests }\end{array}$ & $\begin{array}{l}\text { G1.6 } \\
\text { G1.7 }\end{array}$ & $\begin{array}{l}\text { Beech woodland, } \\
\text { Thermophilous deciduous forest }\end{array}$ \\
\hline \multirow{4}{*}{$\begin{array}{l}\text { LTER Italy site no. } \\
04: \text { Mediterranean } \\
\text { forests }\end{array}$} & $\begin{array}{l}\text { *Monte Rufeno } \\
\text { (Acquapendente - VT) }\end{array}$ & 6.8 .2 & $\begin{array}{l}\text { Turkey oak, Hungarian oak and } \\
\text { Sessile oak forest }\end{array}$ & G1.7 & Thermophilous deciduous forest \\
\hline & $\begin{array}{l}\text { *Ficuzza } \\
\text { (Godrano - PA) }\end{array}$ & 6.8 .2 & $\begin{array}{l}\text { Turkey oak, Hungarian oak and } \\
\text { Sessile oak forest }\end{array}$ & G1.7 & Thermophilous deciduous forest \\
\hline & $\begin{array}{l}\text { *Colognole } \\
\text { (Livorno) }\end{array}$ & 6.9 .1 & Mediterranean evergreen oak forest & $\mathrm{G} 2.1$ & $\begin{array}{l}\text { Mediterranean evergreen oak wood- } \\
\text { land }\end{array}$ \\
\hline & $\begin{array}{l}\text { Monte Rufeno Reserve } \\
\text { (Acquapendente - VT) }\end{array}$ & 6.8 .2 & $\begin{array}{l}\text { Turkey oak, Hungarian oak and } \\
\text { Sessile oak forest }\end{array}$ & G1.7 & Thermophilous deciduous forest \\
\hline $\begin{array}{l}\text { LTER Italy site no. } \\
\text { 18: Castelporziano }\end{array}$ & $\begin{array}{l}\text { Castelporziano forest } \\
\text { (Roma) }\end{array}$ & $\begin{array}{l}6.8 .2 \\
6.9 .1\end{array}$ & $\begin{array}{l}\text { Turkey oak, Hungarian oak and } \\
\text { Sessile oak forest Mediterranean }\end{array}$ & $\begin{array}{l}\text { G1.7 } \\
\text { G2.1 }\end{array}$ & $\begin{array}{l}\text { Thermophilous deciduous forest, } \\
\text { Mediterranean evergreen forest, Low- }\end{array}$ \\
\hline Estate & & 6.10 .1 & $\begin{array}{l}\text { evergreen oak forest, Thermophilous } \\
\text { pine forest }\end{array}$ & G3.7 & land mediterranean pine woodland \\
\hline \multirow[t]{2}{*}{$\begin{array}{l}\text { LTER Italy site no. } \\
\text { 05: Lowland forests }\end{array}$} & $\begin{array}{l}\text { *Bosco Fontana } \\
\text { (Mantova) }\end{array}$ & 6.5 .1 & Peduncolate oak - hornbeam forest & G1.A & $\begin{array}{l}\text { Meso- and eutrophic oak, hornbeam, } \\
\text { ash, sycamore, lime, elm and related } \\
\text { woodland }\end{array}$ \\
\hline & $\begin{array}{l}\text { Bosco Fontana Reserve } \\
\text { (Mantova) }\end{array}$ & 6.5 .1 & Peduncolate oak - hornbeam forest & G1.A & $\begin{array}{l}\text { Meso- and eutrophic oak, hornbeam, } \\
\text { ash, sycamore, lime, elm and related } \\
\text { woodland }\end{array}$ \\
\hline
\end{tabular}


Tab. 4 - Environmental parameters assessed at LTER Italy forest sites. (*): Research stations belonging to the ICP Forests Programme. (a): the station Selva Piana is included in several other networks (FluxNet, CarboEurope-IP, NitroEurope) and research is coordinated by CNRIBAF. $(\diamond)$ : monitoring parameters activated in 2009.

\begin{tabular}{|c|c|c|c|c|c|c|c|c|c|c|c|c|c|c|}
\hline Sites & LTER Italy forest sites & 芯 & 司 & ฮ̊ & 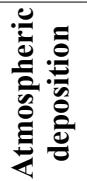 & 异 & $\underset{0}{0}$ & 导 & 苞 & 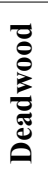 & 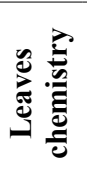 & 完 & 䒿 & 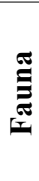 \\
\hline \multirow[t]{5}{*}{ Forests of the Alps } & *Val Masino & $\times$ & $x$ & $x$ & $x$ & $x$ & $\times$ & $x$ & $x$ & $\times$ & $\times$ & $x$ & $x$ & - \\
\hline & $*$ Renon & $\times$ & $x$ & $x$ & $x$ & $x$ & $\times$ & $x$ & $x$ & $x$ & $\times$ & $x$ & $x$ & $x$ \\
\hline & *Passo Lavazè & $\times$ & $x$ & $x$ & $x$ & $x$ & $\times$ & $\times$ & $x$ & $x$ & $\times$ & $x$ & $x$ & $\times$ \\
\hline & *Tarvisio & $\times$ & $\times$ & $\times$ & $x$ & $\times$ & $\times$ & $\times$ & $\times$ & $\times$ & $\times$ & $\times$ & $x$ & - \\
\hline & Valbona Reserve & $\times$ & $\times$ & - & - & $x$ & $\times$ & $\times$ & - & $\times$ & - & $\times$ & $\times$ & $\times$ \\
\hline \multirow[t]{3}{*}{ Apennines forests } & *Selva Piana ${ }^{(a)}$ & $\times$ & $\times$ & $x$ & $x$ & $\times$ & $x$ & $x$ & $x$ & $\times$ & $x$ & $x$ & $x$ & $\times$ \\
\hline & *Piano Limina & $\times$ & $\times$ & $\times$ & $x$ & $x$ & $\times$ & $\times$ & $x$ & $\times$ & $\times$ & $x$ & $x$ & - \\
\hline & Torricchio Reserve & $\times$ & $\times$ & $\times$ & $\times$ & $\times$ & $\times$ & $\times$ & - & - & - & - & $\times$ & $x$ \\
\hline \multirow[t]{4}{*}{ Mediterranean forests } & *Monte Rufeno & $\times$ & $x$ & $\times$ & $x$ & $x$ & $x$ & $x$ & $x$ & - & $x$ & $x$ & $x$ & - \\
\hline & *Ficuzza & $\diamond$ & $x$ & $x$ & $x$ & $x$ & $\times$ & $x$ & $x$ & $x$ & $x$ & $x$ & $x$ & - \\
\hline & *Colognole & $\times$ & $\times$ & $\times$ & $x$ & $\times$ & $\times$ & $\times$ & $x$ & $x$ & $\times$ & $x$ & $x$ & - \\
\hline & Monte Rufeno Reserve & $\times$ & $x$ & - & - & $x$ & $x$ & $x$ & - & - & - & - & $x$ & $\times$ \\
\hline Castelporziano Estate & Castelporziano forest & $\times$ & $x$ & - & - & $\times$ & $\times$ & $\times$ & $\times$ & - & - & $x$ & - & $\times$ \\
\hline \multirow[t]{2}{*}{ Lowland forests } & *Bosco Fontana & $\diamond$ & $\bullet$ & $\times$ & 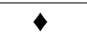 & $\times$ & $\times$ & $\times$ & $x$ & $\times$ & $\times$ & $x$ & - & $x$ \\
\hline & Bosco Fontana Reserve & $\times$ & - & $\times$ & - & $x$ & $\times$ & $\times$ & $x$ & $\times$ & - & $x$ & - & $\times$ \\
\hline
\end{tabular}

dazzo - Siror, Trento; Montagna di Torricchio, central Apennines, Pievetorina and Montecavallo - Macerata; Monte Rufeno Regional Natural Reserve, central Italy, Acquapendente - Viterbo; Castelporziano Estate, central Italy - Rome; Bosco della Fontana State Natural Reserve, Po Valley Mantova), where additional research or monitoring activities are carried out according to national regulations, local management plans, as well as specific projects, thesis etc. In this case, the dataset is often enriched with more data on fauna biodiversity (Tab. 5 ) and the main aim of studies is conservation. The choice of clustering different research stations to form a forest site goes back to the starting phases of the implementation of the national LTER network: it is related to the aim of grouping different research stations, saving long and uninterrupted datasets, in major forest ecosystem types, also highlighting cooperation among several institutes responsible for different research lines. The ongoing processes of restructuring the European network and harmonizing monitoring activities will presumably lead to the selection of some stations that, while stil complying with LTER criteria, will be specifically able to sustain research plans on common questions, parameters and methods as individual long term ecological research sites.

Examples of research and monitoring from LTER Italy forest sites

In this section, we present some examples of monitoring and research projects implemented at LTER Italy forest sites. We selected these projects to illustrate the research cooperation among different institutes. In addition, we also discuss the CONECOFOR Programme, which includes one or more research stations in each LTER Italy forest site.

\section{The CONECOFOR Programme}

The CONECOFOR Programme is a long lasting forest monitoring programme started in Italy in 1995 under Regulation (EC) no. 1091/94 and the Convention on Long Range Transboundary Air Pollution of United-Nations Economic Commission for Europe (CLRTAP UN/ECE - Petriccione \& Pompei 2002, Ferretti et al. 2006). At its beginning, the programme included 20 monitoring plots in forest ecosystems, selected on the base of their suitability to represent forest types in Italy and to provide rich datasets on environmental conditions. Later, new monitoring stations were incorporated to reach a total of 31 study areas in 2005. The investigations carried out at the permanent monitoring plots include crown condition assessment, chemical content of soil and foliage, deposition chemistry, tree growth, ground vegetation, meteorological conditions (Ferretti et al. 2006). At selected plots, litter fall, leaf area index, chemistry of soil solution and advanced soil parameters are also monitored. Additional biodiversity parameters (epiphytic lichens, deadwood, invertebrates) were studied in 2003 (http://www.forestbiota.org). The collected data are regularly submitted to the relevant bodies responsible for the database, including QA/QC data policy. From 1995 to 2000 , the data collected from all CONECOFOR plots under Regulation (EC) no. 1091/94 were submitted to the FIMCI (Forest Intensive Monitoring Coordinating Institute, The Netherlands); data gathered from 2001 to 2006 under Regulation (EC) no. 2152/2003 (Forest Focus) were submitted to the European Commission Joint Research Centre (Ispra, Italy). After Forest Focus regulation expiration in 2006, monitoring activities have been carried out under the financial support of the Project "FutMon", a LIFE+ Project for the implementation of a European forest monitoring system (http://www.futmon.org/). CONECOFOR study areas and the activities implemented at plot level have been the basis for several studies about forest conditions (Petriccione et al. 2009a), effects of climate change on forest ecosystems (Petriccione et al. 2009b), biodiversity assessment (Bredemeier et al. 2007). Ten of these monitoring stations are today included in 4 LTER Italy forest sites.

\section{The EFOMI Project}

Between 2001 and 2004, the EFOMI Project (Ecological Evaluation in Alpine Forest Ecosystems by Integrated Monitoring http://www.iasma.it/sperimentazione_context.jsp?ID_LINK=2424\&area=6), funded by the Autonomous Province of Trento and coordinated by the Istituto Agrario di San Michele all'Adige (Trento, Italy) had the aim of assessing the health status of Trentino (north-east Italy) woodlands. Two sites were investigated for several ecosystem parameters, including climate, air, soil and water chemistry, vegetation and selected animal communities. One of the study areas (Passo Lavazè, Trento) is a subalpine spruce forest belonging to the ICP Forests Programme and the LTER Italy forest site "Forests of the Alps". The general objectives of the Project were: (1) to achieve an in-depth knowledge of mechanisms regulating the ecological sta- 
bility of forest stands, especially in relation to the main disturbance factors; (2) to clarify alterations in the complexity of forest ecosystems, induced by direct and indirect impacts and climate change. Within Work Package 5 of the Project, a characterization of zoocoenoses in relation to main environmental factors was developed, with regards to some insects (Lepidoptera, Coleoptera, Auchenorrhynca, Collembola) and small mammals communities. The Project contributed to the increase of collected data since 1992 and could assess the health state of the monitored forest stands and the high level of biodiversity of flora and fauna (Salvadori \& Ambrosi 2005)

\section{Bosco della Fontana State Natural Re-} serve

Bosco della Fontana (Mantova, northern Italy) is one of the last remaining portions of floodplain forest in the central Po plain After 1950, forest management operations were gradually decreased and then completely interrupted (1990) and, although the total surface of the forest was heavily reduced (233 ha), quantities of live and dead wood have remarkably increased. The forest is a Biogenetic Nature Reserve since 1977 inserted in the Nature 2000 network as SPZ (Special Protected Zone) since 1998 and as SCIp (Site of Community Importance) since 2004. Bosco della Fontana is part of LTER Italy, as a single station within the "Lowland forests" site and is listed in the Italian Herpetological Society as a "Herpetological Area of National Relevance". Research is coordinated by the Bosco della Fontana National Center for the Study and the Conservation of Forest Biodiversity, which is specialized in invertebrate taxonomy and deadwood, in a context of the long term monitoring of forest dynamics (Cerretti et al. 2004a). The structure of the forest is gradually evolving from a mixed coppice to more mature stages that may eventually lead to old growth forest. Currently alien species (Quercus rubra L., Juglans nigra L, Platanus spp.) are being eliminated and changed into deadwood and microhabitats for saproxylic organisms in the context of a Life Nature project for the restoration of deadwood and conservation of saproxylic fauna (LIFE Natura Project NAT/IT/99/6245 "Techniques for re-establishment of dead wood for saproxylic fauna conservation" Cavalli \& Mason 2003, Mason et al. 2003). Forest dynamics at Bosco della Fontana are monitored with a 10-year frequency in three permanent "nested" Core Areas. The monitoring developed in the Core Areas includes structural parameters (e.g., eight dendrometric measures for each georeferenced tree) and qualitative parameters (e.g., state of deadwood, biotic and abiotic damage), according to the method of Koop's SILVI-

Tab. 5 - Animal groups investigated at LTER Italy forest sites. $(*)$ : research stations belonging to the ICP Forests Programme.

\begin{tabular}{llccccc}
\hline \multirow{5}{*}{ Sites } & LTER Italy forest sites & & & & \\
& & & & & \\
& & & & & \\
\hline Forests of the Alps & *Val Masino & $\mathrm{x}$ & - & - & - & - \\
& *Renon & $\mathrm{x}$ & - & - & - & $\mathrm{x}$ \\
& *Passo Lavazè & $\mathrm{x}$ & - & - & - & - \\
& *Tarvisio & $\mathrm{x}$ & - & - & - & - \\
& Valbona Reserve & - & - & - & $\mathrm{x}$ & $\mathrm{x}$ \\
\hline Apennines forests & *Selva Piana & $\mathrm{x}$ & - & - & $\mathrm{x}$ & - \\
& *Piano Limina & $\mathrm{x}$ & - & - & - & - \\
& Torricchio Reserve & $\mathrm{x}$ & - & $\mathrm{x}$ & - & $\mathrm{x}$ \\
\hline Mediterranean forests & *Monte Rufeno & $\mathrm{x}$ & - & $\mathrm{x}$ & $\mathrm{x}$ & $\mathrm{x}$ \\
& *Ficuzza & $\mathrm{x}$ & $\mathrm{x}$ & $\mathrm{x}$ & $\mathrm{x}$ & - \\
& *Colognole & $\mathrm{x}$ & $\mathrm{x}$ & $\mathrm{x}$ & $\mathrm{x}$ & - \\
& Monte Rufeno Reserve & $\mathrm{x}$ & - & $\mathrm{x}$ & $\mathrm{x}$ & $\mathrm{x}$ \\
\hline Castelporziano Estate & Castelporziano forest & - & - & - & $\mathrm{x}$ & $\mathrm{x}$ \\
\hline Lowland forests & *Bosco Fontana & $\mathrm{x}$ & $\mathrm{x}$ & $\mathrm{x}$ & $\mathrm{x}$ & $\mathrm{x}$ \\
& Bosco Fontana Reserve & $\mathrm{x}$ & $\mathrm{x}$ & $\mathrm{x}$ & $\mathrm{x}$ & $\mathrm{x}$ \\
\hline
\end{tabular}

STAR program (Koop 1989); a central area nested within each Core Area is dedicated to monitoring of the dynamics of the herbaceous layer. The data from the core areas are interpreted with the Oldeman silvigenetic theory (Oldeman 1990) and regularly updated every 10 years (Mason 2002). Recently, studies on three-dimensional (3D) structure of the forest using Light Detection and Ranging (LiDAR) technique (Gianelle et al. 2007) were carried out in order to investigate relationships between $3 \mathrm{D}$ structure, arthropods biodiversity and habitat (Cerretti et al. 2004b, Stireman et al. 2011). An ICP Forests plot was set up at Bosco della Fontana in 2005.

\section{The Valbona Forest Reserve}

The Valbona forest reserve is located in Trentino (Oriental Alps), between 1500 and $2100 \mathrm{~m}$ a.s.l. It is included in the Paneveggio State forest, belonging to the Autonomous Province of Trento and is part of the natural park Paneveggio and Pale di S. Martino (Predazzo-Siror, Trento). The main purpose of the forest reserve is to develop forest management practices complying with biological processes, in order to address both protection and production values. Silviculture on spruce stands has been the object of studies in Paneveggio for more than 200 years. The Valbona Forest Reserve is divided into two parts: a 50 ha reserve for forestry applied research and a wider strict reserve for LTER. Between 1994 and 2004, six longterm 1-ha ecological permanent plots have been established, along an altitudinal gradient. The Universities of Turin and Florence have been carrying out measurements on living trees and deadwood, together with interpretation of records from historic archives. This investigation allowed to map the present forest structure. Results also underlined the importance of long term research to understand dynamics over long time scales: evidence has been achieved that the expansion of forest area towards the upper altitudinal belt is mainly due to land use change and relief from grazing and human forest exploitation, while tree growth processes are related to climate fluctuations, especially regarding summer temperature (Motta \& Piussi 2009).

\section{Selva Piana intensive research and monitoring site}

The research station Selva Piana, included in the site "Forests of the Apennines", is another particular case within the Italian LTER Network. The station is located near the village of Collelongo (Abruzzo region, central Italy), close to the external belt of the Abruzzo, Lazio and Molise National Park. The Selva Piana forest stand $\left(41^{\circ} 50^{\prime} 58^{\prime \prime} \mathrm{N}\right.$, $13^{\circ} 35^{\prime} 17^{\prime \prime}$ E, 1560 m elevation) belongs to a 3000 ha forest community that is part of a wider forest area. The environmental and structural conditions of the stand are representative of central Apennines beech forests. The experimental facility was established in 1991 to study ecology and silviculture of typical Apennines beech forests (Scarascia Mugnozza 1999). In 1993-1994, the first tower in Europe to measure carbon and water vapor exchange between forest and atmosphere was installed at the station (Valentini et al. 1996). In 1995-1996, the station was one of the first permanent monitoring plots within the CONECOFOR monitoring network, under the ICP Forests programme. The site is currently equipped with a $26 \mathrm{~m}$ high scaffold tower with an additional mast reaching $32 \mathrm{~m}$, approximately $8-10 \mathrm{~m}$ above the canopy. Together with the classic vari- 
ables of the CONECOFOR programme, ecosystem water and $\mathrm{CO}_{2}$ fluxes have been measured since 1993 with the eddy-covariance technique (Valentini et al. 1996, Valentini et al. 2000, Scartazza et al. 2004). Leaf Area Index, litter production and other ecosystem parameters are measured on seasonal or annual basis (Cutini et al. 1998), while detailed data on above- and below-ground primary productivity are available at regular intervals (Scarascia $\mathrm{Mu}$ gnozza et al. 2000, Luyssaert et al. 2009). The station, further to LTER, is currently part of the following networks: FluxNet (CarboEurope and CarboItaly), ICP Forests, ICP IM, FAO-GTOS, NitroEurope. In this respect, the station represents an example of cooperation efforts among research and monitoring that is also at the base of LTER way of operation.

\section{Consistency of ecological datasets at Italian forest sites}

The dataset built within the ICP Forests Programme is a relatively long one: data series started in 1995 in most cases and are still ongoing. Moreover, the ICP Forests Programme has produced standardized data, collected according to shared and harmonized protocols available on line (http://www.icp-forests.org, http://www.forestbiota.org). The dataset concerns mainly the vegetation component of forest ecosystems and particularly processes regarding vegetation and the effects of abiotic variables on crowns and growth of tree species, leaves chemistry, soil chemistry (Ferretti et al. 2006). At the interface between abiotic variables and forest conditions there is a strong potential for ecological investigations. This potential has not been fully exploited yet, not only at plot level, but also for inter-site comparisons. Deadwood sampling, for example, is currently implemented at several research stations. Even though the plot size, the aims of studies and methods are different, the focal point represented by this common measurement among sites should be taken into consideration as a starting step toward harmonization. A gap is also to be recognized in data concerning consumers and biodiversity (Magurran et al. 2010). Invertebrates were monitored for three years in the frame of a pilot project (http://www.forestbiota.org Ferretti et al. 2006) and sporadic case studies can be found concerning other animal groups, but a continuous and coordinated monitoring is not currently performed. Though the plot scale is not suited for investigations on spatial and temporal distribution of animal populations, some data on consumers would be of relevance for considerations on their impact on primary production, organic matter accumulation and overall evaluation of energy transformation, environmental stability and quality of ecosystems. Within the network, insects and birds are among the most investigated animal groups (Tab. 5). Different methods are currently available to survey and sample insects, depending on the aims of the study and the ecological traits of target families and study areas. Also, a wide and shared methodology is available for bird monitoring at LTER Europe level (Vadineanu et al. 2005). So, specific working groups would be necessary to start or enhance harmonization of methods, based on the mentioned common parameters. The already existing research lines should be considered and maintained, while experiences from LTER Europe members show that overlaps and shifts of methods are possible (Sykes \& Lane 1996). On a different ground, datasets from natural reserves included in LTER Italy forest sites have a stronger emphasis on both producers' and consumers' components of ecosystems. These datasets address specific ecological questions on processes, relying on data series going back in several cases to past centuries; however methods, duration, intensity and interval of sampling and even taxonomic targets often differ from one case to another, thus making harmonization and comparison between studies very difficult (Magurran et al. 2010).

Moreover, ecological issues of global concern should also be considered. Examples of LTER activities addressing biodiversity loss, climate change, land use change at large scale exist in LTER Europe: in UK LTER Network, ground beetles (Coleoptera, Carabidae) and the ubiquitous harvestman Mitopus morio are monitored at terrestrial sites for species abundance and features responding to climate change and changes in land management (Sykes \& Lane 1996, Morecroft et al. 2009). Although not directly linked to LTER Europe, another example is the estimation of the effect of the 2003 heat wave on European ecosystems' carbon balance, that was assessed using data from research and monitoring networks, remote sensing and process modeling.

Tab. 6 - Potential suitability of LTER Italy forest research stations to address five suggested LTER core areas and current ecological issues of global concern. $(*)$ : research stations belonging to the ICP Forests Programme. $(\mathrm{x})$ : potential suitability of research station to address the corresponding question.

\begin{tabular}{|c|c|c|c|c|c|c|c|c|c|}
\hline Sites & LTER Italy forest sites & 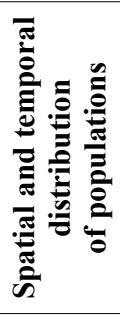 & 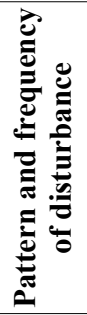 & 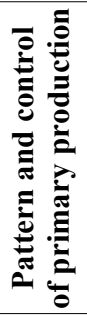 & 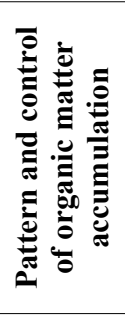 & 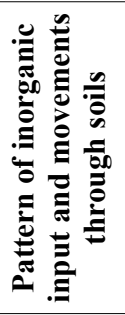 & 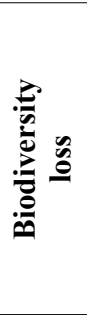 & 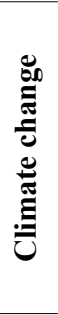 & 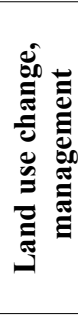 \\
\hline \multirow[t]{5}{*}{ Forests of the Alps } & *Val Masino & - & $\mathrm{x}$ & $\mathrm{x}$ & $\mathrm{x}$ & $\mathrm{x}$ & - & $\mathrm{x}$ & - \\
\hline & *Renon & - & $\mathrm{x}$ & $\mathrm{x}$ & $\mathrm{x}$ & $\mathrm{x}$ & $\mathrm{x}$ & $\mathrm{x}$ & - \\
\hline & *Passo Lavazè & $\mathrm{x}$ & $\mathrm{x}$ & $\mathrm{x}$ & $\mathrm{x}$ & $\mathrm{x}$ & $\mathrm{x}$ & $\mathrm{x}$ & - \\
\hline & *Tarvisio & - & $\mathrm{x}$ & $\mathrm{x}$ & $\mathrm{x}$ & $\mathrm{x}$ & - & $\mathrm{x}$ & - \\
\hline & Valbona Reserve & $\mathrm{x}$ & $\mathrm{x}$ & $\mathrm{x}$ & - & $\mathrm{x}$ & $\mathrm{x}$ & $\mathrm{x}$ & $\mathrm{x}$ \\
\hline \multirow[t]{3}{*}{ Apennines forests } & *Selva Piana & - & $\mathrm{x}$ & $\mathrm{x}$ & $\mathrm{x}$ & $\mathrm{x}$ & - & $\mathrm{x}$ & - \\
\hline & *Piano Limina & - & $\mathrm{x}$ & $\mathrm{x}$ & $\mathrm{x}$ & $\mathrm{x}$ & - & $\mathrm{x}$ & - \\
\hline & Torricchio Reserve & $\mathrm{x}$ & $\mathrm{x}$ & $\mathrm{x}$ & - & $\mathrm{x}$ & $\mathrm{x}$ & $\mathrm{x}$ & $\mathrm{x}$ \\
\hline \multirow[t]{4}{*}{ Mediterranean forests } & *Monte Rufeno & - & $\mathrm{x}$ & $\mathrm{x}$ & $\mathrm{x}$ & $\mathrm{x}$ & $\mathrm{x}$ & $\mathrm{x}$ & - \\
\hline & $*$ Ficuzza & - & $\mathrm{x}$ & $\mathrm{x}$ & $\mathrm{x}$ & $\mathrm{x}$ & - & $\mathrm{x}$ & - \\
\hline & *Colognole & - & $\mathrm{x}$ & $\mathrm{x}$ & $\mathrm{x}$ & $\mathrm{x}$ & - & $\mathrm{x}$ & - \\
\hline & Monte Rufeno Reserve & $\mathrm{x}$ & $\mathrm{x}$ & $\mathrm{x}$ & - & $\mathrm{x}$ & $\mathrm{x}$ & $\mathrm{x}$ & $\mathrm{x}$ \\
\hline \multirow{3}{*}{$\begin{array}{l}\text { Castelporziano Estate } \\
\text { Lowland forests }\end{array}$} & Castelporziano forest & $\mathrm{x}$ & $\mathrm{x}$ & - & - & - & $\mathrm{x}$ & $\mathrm{x}$ & $\mathrm{x}$ \\
\hline & *Bosco Fontana & $\mathrm{x}$ & $\mathrm{x}$ & $\mathrm{x}$ & $\mathrm{x}$ & $\mathrm{x}$ & $\mathrm{x}$ & $\mathrm{x}$ & - \\
\hline & Bosco Fontana Reserve & $\mathrm{x}$ & $\mathrm{x}$ & $\mathrm{x}$ & $\mathrm{x}$ & - & $\mathrm{x}$ & $\mathrm{x}$ & $\mathrm{x}$ \\
\hline
\end{tabular}


Box 1 - Useful links.

- A long-term biodiversity, ecosystem and awareness research network. Home page.

[online] URL: http://www.alter-net.info/

- Corpo Forestale dello Stato. Home page.

[online] URL: http://www3.corpoforestale.it/flex/cm/pages/ServeBLOB.php/L/IT/IDPagina/443

- EFOMI: Ecological valuation in alpine forest ecosystems by integrated monitoring. Home page.

[online] URL: http://www.iasma.it/sperimentazione_context.jsp?

ID_LINK $=2424 \&$ area $=6$

- Environmental quality and pressure assessment across Europe: the LTER Network as an integrated and shared system for ecosystem monitoring. EnvEurope LIFE co-financed project (2010-2013). Home page.

[online] URL: http://www.enveurope.eu/

- ForestBIOTA - forest biodiversity test-phase assessment. A forest biodiversity monitoring project developed by 10 European countries. Home page.

[online] URL: http://www.forestbiota.org

- Further development and implementation of an EU-level forest monitoring system. A

LIFE co-financed project. Home page.

[online] URL: http://www.futmon.org/

- Long term ecological research Italy. Home page.

[online] URL: http://www.lteritalia.it/

- International co-operative programme on assessment and monitoring of air pollution effects on forests - ICP forests. Home page.

[online] URL: http://www.icp-forests.org

- European long term ecosystem research network. Home page.

[online] URL: http://www.lter-europe.net/

- International long term ecological research network. Home page.

[online] URL: http://www.ilternet.edu/

Methodology, methods and protocols in long term ecological research

The value of consistent methodology is widely recognized in long term ecological research (Beard et al. 1999). The words "methodology", "method" and "protocol" are often used as if they had the same meaning, somehow as synonymous. But actually they are not. The meaning of the word methodology is intended here as collection, comparative study and critical appraisal of individual methods (Patton 2002). In the frame of long term research, methodology should be developed: (1) across sites, to meet harmonization of monitoring or research and shape a restructured international network design; (2) at single site level, in order to set well-ground plans for new monitoring or research activities based on locally available datasets. Through this procedure, it would be also possible to create agreed protocols (Sykes \& Lane 1996, Morecroft et al. 2009). A protocol (Sykes \& Lane 1996) has to be defined as a written method for the design and implementation of experiments; it is usually a comprehensive document, also including lists of required sampling equipment, explanations of statistical analysis, rules to avoid bias. In a protocol, metadata on methods should also be fully registered and stored (Peters 2010), with detailed description of their time and space traits, equipment and suppliers, chronology of sampling, staff involved and others (Beard et al. 1999). Few national LTER networks currently have agreed protocols for the implementation of activities at sites (Sykes \& Lane 1996), but several of them share the objective of drafting protocols as common manuals for future monitoring or research steps.

In order to start with a sound planning of harmonization of research and monitoring in LTER Italy forest sites, a cross analysis of current activities with LTER ecological questions could be a first step, thus trying to answer the question: "Can LTER question «Y» be approached using dataset components of «forest site $\mathrm{X}$ » (Tab. 6)? While some researchers suggested that research questions could be profitably addressed by most of the stations (disturbance, primary production, soil chemistry, climate change), population dynamics and land use change can be properly investigated at a scale larger than plot level. An example of such questions can be provided by those sites included in protected areas, where ecological investigations are not carried out intensively at plot level, but considering a larger spatial scale and the relationship with the landscape. Additionally, up-scaling schemes, starting from plot level intensive surveys, should be designed to use results at plot level to understand broader-scale processes.

\section{Conclusions}

After decades (in some cases more than a century) of monitoring and research on key environmental variables, the inclusion of selected forest study sites in the LTER Italian Network is a due and positive outcome. Today, the main forest ecosystems are represented in the national network. Through a strong coordination effort, LTER Italy has achieved awareness at national level and a foremost representation outside national borders, within the global and European LTER entities (ILTER and LTER Europe). LTER Italy forest sites reflect strengths and weaknesses of international networks. In fact, on one side, there are good examples of cooperation in terms of the institutions involved, while the set of fundamental variables assessed and the length of data series represent invaluable monitoring and research resources. On the other side, the bottom-up process of network implementation created a poorly harmonized collection of sites, where an overall agreement on key parameters seems evident, but methods are still very diversified and need to be discussed among experts. This is necessary in order to shift from in-site monitoring to inter-site and cross-site research and evaluation on ecosystem processes. Indeed, the framework of LTER, at national and international level, provides now the ground for starting this kind of discussion. As it is widely recommended to keep the existing set of variables unchanged as far as possible (to maintain the continuity of data series), a possible way is to start an adaptive monitoring following a specific research question, chosen among those suggested within LTER and adapted to the existing dataset. There is a potential frame to compare and eventually adjust measurements, in terms of methods, to the request of standardization of activities across sites and also across different networks. This process of harmonization of activities could also facilitate soundness of research results and enhance the benefits of long term research knowledge to the general public and the policy. The LIFE co-financed project EnvEurope, "Environmental quality and pressure assessment across Europe: the LTER Network as an integrated and shared system for ecosystem monitoring" (2010-2013, http://www.enveurope.eu/) has the main objectives of investigating these opportunities, developing a consistent classification of sites and network design.

\section{Acknowledgements}

We would like to thank Enrico Pompei (Head Director of Environmental Monitoring and CONECOFOR Office, National Forest Service) and Franco Mason (Head Director of the National Centre for the Study and the Conservation of Forest Biodiversity, National Forest Service) for the support and active participation committed to all LTER initiatives. We would like also to thank 
Andrea Rapisarda and Bruno Petriccione (National Forest Service) for having promoted LTER Italy since its inception. We are grateful to Alessandra Pugnetti (National Council for Research; LTER Italy and EnvEurope LIFE Project coordinator), who suggested several articles cited in the present paper and to the LTER Europe community which contributed to several aspects discussed here. We acknowledge the Project ALTERNet (A Long-Term Biodiversity, Ecosystem and Awareness Research Network), funded under the EU Sixth Framework Programme, that contributed to enlarge and strengthen participation inside LTER Europe. Funding from LIFE projects FutMon (LIFE07 ENV/D/000218) and EnvEurope (LIFE08 ENV/IT/000399) is greatly acknowledged.

\section{References}

Beard GR, Scott WA, Adamson JK (1999). The value of consistent methodology in long-term environmental monitoring. Environmental Monitoring and Assessment 54 (3): 239-258. - doi: 10.1023/A:1005917929050

Bredemeier M, Dennis P, Sauberer N, Petriccione B, Torok K, Cocciufa C, Morabito G, Pugnetti A (2007). Biodiversity assessment and change. The challenge of appropriate methods. In: "Issues in environmental science and technology. Biodiversity under threat" (Hester RE, Harrison RM eds). The Royal Society of Chemistry, Cambridge ,UK, vol. 5, pp. 217-240.

Campanaro A, Hardersen S, Mason F (2007). Piano di gestione della riserva naturale statale e sito natura 2000 "Bosco della Fontana". Quaderni Conservazione Habitat 4, Cierre Ed., Verona, Italy, pp. 221

Cavalli R, Mason F (2003). Techniques for re-establishment of dead wood for saproxylic fauna conservation. LIFE Nature project NAT/IT/ 99/6245 "Bosco della Fontana" (Mantova, Italy). Scientific report 2, Centro Nazionale per lo Studio e la Conservazione della Biodiversità Forestale di Verona - Bosco della Fontana, Gianluigi Arcari Ed., Mantova, Italy, pp. 112.

Cerretti P, Hardersen S, Mason F, Nardi G, Tisato M, Zapparoli M (2004a). Ricerche naturalistiche a Bosco della Fontana. Quaderni Conservazione Habitat 3, Cierre Ed., Verona, Italy, pp. 96.

Cerretti P, Whitmore S, Mason F, Vigna Taglianti A (2004b). Survey on the spatio-temporal distribution of Tachinid flies using Malaise traps (Diptera, Tachinidae). In: "Invertebrati di una foresta della Pianura Padana. Bosco della Fontana. Secondo contributo" (Cerretti P, Hardersen S, Mason F, Nardi G, Tisato M, Zapparoli $\mathrm{M}$ eds). Conservazione Habitat Invertebrati 3, Cierre Ed., Verona, Italy, pp. 229-256.

Cutini A, Matteucci G, Scarascia Mugnozza G (1998). Estimation of leaf area index with the LiCor LAI 2000 in deciduous forests. Forest Ecology and Management 105 (1-3): 55-65. - doi: 10.1016/S0378-1127(97)00269-7

European Environment Agency (2007). European forest types. Categories and types for sustainable forest management reporting and policy. Technical Report no. 9/2006, $2^{\text {nd }}$ Edition, Copenhagen, Denmark.

Ferretti M, Petriccione B, Fabbio G, Bussotti F (2006). Aspects of biodiversity in selected forests ecosystems in Italy: status and changes over the period 1996-2003. Third report of the task force on integrated and combined (I \& C) evaluation of the CONECOFOR programme. Annali Istituto Sperimentale per la Selvicoltura 30 (2): 112.

Gianelle D, Travaglini D, Mason F, Minari E, Chirici G, Chemini C (2007). Canopy analysis and dynamics of a floodplain forest. Scientific report 3, Centro nazionale per lo studio e la conservazione della biodiversità forestale di Verona - Bosco della Fontana, Cierre Ed., Verona, Italy, pp. 96.

Kaufmann H, Anderson M (2006). ILTER Strategic Plan. Environment \& Enterprise Strategies, LLC, USA.

Koop H (1989). Forest dynamics, SILVI-STAR: a comprehensive monitoring system. Springer, Berlin, Heidelberg, New York, pp. 229.

Likens GE (1989). Long-term studies in ecology. Springer-Verlag, New York, USA

Lindenmayer DB, Likens GE (2009). Adaptive monitoring: a new paradigm for long-term research and monitoring. Trends in Ecology and Evolution 24 (9): 482-486. - doi: 10.1016/j.tree. 2009.03.005

Luyssaert S, Reichstein M, Schulze ED, Janssens IA, Law BE, Papale D, Dragoni D, Goulden M, Granier A, Kutsch WL, Linder S, Matteucci G, Moors E, Munger JW, Pilegaard K, Saunders M, Falge EM (2009). Towards a consistency crosscheck of eddy covariance flux based and biometric estimates of ecosystem carbon balance. Global Biogeochemical Cycles 23: GB3009. doi: 10.1029/2008GB003377

Magurran AE, Baillie SR, Buckland ST, Dick JM, Elston DA, Scott EM, Smith RI, Somerfield PJ, Watt AD (2010). Long-term datasets in biodiversity research and monitoring: assessing change in ecological communities through time. Trends in Ecology and Evolution 25 (10): 574582. - doi: 10.1016/j.tree.2010.06.016

Mason F (2002). Dinamica di una foresta della pianura Padana. Primo contributo, monitoraggio 1995. Rapporti scientifici 1, Centro Nazionale per lo Studio e la Conservazione della Biodiversità Forestale di Verona - Bosco della Fontana, Gianluigi Arcari Ed., Mantova, Italy, pp. 208.

Mason F, Nardi G, Tisato M (2003). Proceedings of the International Symposium "Dead wood: a key to biodiversity" (Mason F, Nardi G, Tisato M eds). Mantova (Italy), 29-31 May 2003. Sherwood 95 (2): 99.

Mirtl M, Frenzel M, Furman E, Ohl C, Krauze K, Grünbühel C (2008). LTER Europe criteria and recommendations. LTER Europe Report. [online] URL: http://www.uibk.ac.at/alpinerraum/ meetings/lter/lter europe criteria.pdf

Morecroft M, Bealey C, Beaumont D, Benham S,
Brooks D, Burt T, Critchley C, Dick J, Littlewood N, Monteith D (2009). The UK Environmental Change Network: emerging trends in the composition of plant and animal communities and the physical environment. Biological Conservation 142 (12): 2814-2832. - doi: 10.1016/j.biocon.2009.07.004

Motta R, Piussi P (2009). Ricerche ecologiche di lungo periodo (LTER) nella riserva forestale della Valbona (Paneveggio, TN). In: "Atti del Terzo Congresso Nazionale di Selvicoltura" (Ciancio O ed). Taormina (ME - Italy), 16-19 October 2008. Accademia Italiana di Scienze Forestali, Firenze, Italy, pp. 558-562.

Oldeman RAA (1990). Forests: elements of silvology. Springer-Verlag, New York, Berlin, Heidelberg, pp. 624

Parr TW, Ferretti M, Simpson IC, Forsius M, Kovacs-Lang E (2002). Towards a long-term integrated monitoring programme in Europe: network design in theory and practice. Environmental Monitoring and Assessment 78 (3): 253290. - doi: 10.1023/A:1019934919140

Patton MQ (2002). Qualitative research and evaluation methods ( $3^{\text {rd }}$ edn.). Thousand oaks, Sage Publications, CA, USA.

Peters DP (2010). Accessible ecology: synthesis of the long, deep, and broad. Trends in Ecology and Evolution 25 (10): 592-601. - doi: 10.1016/j.tree. 2010.07.005

Petriccione B, Pompei E (2002). The CONECOFOR programme: general presentation, aims and coordination. In: "Long term ecological research in Italian forest ecosystems" (Mosello R, Petriccione B, Marchetto A eds). Journal of Limnology 61 (1) 3-11. [online] URL: http://www. iii.to.cnr.it/pubblicaz/JL_61_supl/JL61_Supplindex.htm

Petriccione B, Cindolo C, Cocciufa C, Ferlazzo S, Parisi G (2009a). Un indicatore dello stato della biodiversità delle foreste europee. In: "Atti del Terzo Congresso Nazionale di Selvicoltura" (Ciancio O ed). Taormina (ME- Italy) 16-19 October 2008. Accademia Italiana di Scienze Forestali, Firenze, Italy, pp. 240-242.

Petriccione B, Cindolo C, Cocciufa C, Ferlazzo S, Parisi G (2009b). Gli effetti dei cambiamenti climatici sugli ecosistemi forestali. In: "Atti del Terzo Congresso Nazionale di Selvicoltura" (Ciancio O ed). Taormina (ME - Italy) 16-19 October 2008. Accademia Italiana di Scienze Forestali, Firenze, Italy, pp. 570-574.

Risser PG (1991). Long-term ecological research. An international perspective. John Wiley and Sons, Chichester, New York, Brisbane, Toronto, Singapore.

Salvadori C, Ambrosi P (2005). Ecological evaluation in alpine forest ecosystems by integrated monitoring. Studi Trentini di Scienze Naturali, Acta Biologica 81 (1): 31-40.

Scarascia Mugnozza G (1999). Ecologia strutturale e funzionale di faggete italiane. Edagricole, Bologna, Italy, pp. 133-183.

Scarascia Mugnozza G, Bauer G, Persson H, Matteucci G, Masci A (2000). Tree biomass, growth and nutrient pools. In: "Carbon and nitrogen cyc- 
ling in european forest Ecosystems" (Schulze ED ed). Ecological Studies 142, Springer Verlag, Heidelberg, Germany, pp 49-62.

Scartazza A, Mata C, Matteucci G, Yakir D, Moscatello S, Brugnoli E (2004). Comparisons of $\delta^{13} \mathrm{C}$ of photosynthetic products and ecosystem respiratory $\mathrm{CO}_{2}$ and their responses to seasonal climate variability. Oecologia 140 (2): 340-351. - doi: 10.1007/s00442-004-1588-1

Seastedt TR, Briggs JM (1991). Long-term ecological questions and considerations for taking long-term measurements: lessons from the LTER and FIFE programs on Tallgrass Prairie. In: "Long-term ecological research. An international perspective" (Risser PG ed). John Wiley and Sons, Chichester, New York, Brisbane, Toronto, Singapore.

Stireman III JO, Cerretti P, Whitmore D, Hardersen S, Gianelle D (2011). Composition and stratification of a tachinid (Diptera: Tachinidae) parasitoid community in a European temperate plain forest. Insect Conservation and Diversity [early online]. - doi: 10.1111/j.1752-4598.2011. 00168.x4598.2011.00168.x

Strayer D, Glitzenstein JS, Jones CG, Kalasa J, Likens GE, McDonnell MJ, Parker GG, Pickett STA (1986). Long term ecological studies: an illustrated account of their design, operation and importance to ecology. Occasional Pubblication no. 2, Institute of Ecosystem Study, Millbrook, New York, USA, pp. 38.

Sykes JM, Lane AMJ (1996). The United Kingdom environmental change network. Protocol for standard measurements at terrestrial sites. The Stationery Office, Natural Environment Research Council, London, UK, pp. 219.

Sutherland WJ (2006). Ecological census techniques: a handbook. Cambridge University Press, Cambridge, UK.

Vadineanu A, Datcu S, Adamescu M, Cazacu C
(2005). The state of the art for LTER activities in Europe. ALTER-Net WP I3 Report, Department of Systemic Ecology, University of Bucharest, Romania.

Valentini R, Angelis P, Matteucci G, Monaco R, Dore S, Mugnozza GE (1996). Seasonal net carbon dioxide exchange of a beech forest with the atmosphere. Global Change Biology 2 (3): 199207. - doi: 10.1111/j.1365-2486.1996.tb00072.x Valentini R, Matteucci G, Dolman AJ, Schulze ED, Rebmann C, Moors EJ, Granier A, Gross P, Jensen NO, Pilegaard K, Lindroth A, Grelle A, Bernhofer C, Grünwald T, Aubinet M, Ceulemans R, Kowalski AS, Vesala T, Rannik Ü, Berbigier P, Loustau D, Guðmundsson J, Thorgeirsson $\mathrm{H}$, Ibrom A, Morgenstern $\mathrm{K}$, Clement R, Moncrieff J, Montagnani L, Minerbi S, Jarvis PG (2000). Respiration as the main determinant of carbon balance in European forests. Nature 404 (6780): 861-865. - doi: 10.1038/35009084 